\title{
Profesní start absolventek studijního oboru Sociální pedagogika a poradenství - období pregraduální př́ípravy ${ }^{1}$
}

\author{
Career start of social pedagogy and counseling graduates - the period of undergraduate \\ preparation \\ Martina Kánská
}

\begin{abstract}
Abstrakt: Cílem tohoto př́spěvku je seznámit čtenáře s prvními výsledky realizovaného kvalitativního výzkumného šetření, jehož záměrem bylo zmapovat profesní start absolventek studijního oboru Sociální pedagogika a poradenství. V tomto př́spěvku jsou charakterizovány dílčí fáze profesního startu $\mathrm{v}$ období pregraduální prrípravy absolventek, $\mathrm{s}$ ohledem na získávání vlastních zkušeností z praxe. Charakteristiky fází profesního startu $\mathrm{v}$ období pregraduální přípravy zahrnují rovněž odpovědi na otázku, jakou roli měl kontakt s realitou praxe v dílčích fázích profesního startu u dotazovaných absolventek.
\end{abstract}

Klíčová slova: absolventka, dílčí fáze, kontakt s realitou praxe, profesní start, sociální pedagog

\begin{abstract}
A goal of this paper is to introduce the reader with the first results of realized qualitative research investigation, whose aim was to map out career start of social pedagogy and counselling graduates. In this paper partial phases of career start in the period of undergraduate preparation are characterized, with a view to obtaining their own experiences from practice. The phase characteristics of career start in the period of undergraduate preparation include answers to the question, what is the role of contact with the reality of practice in partial phases of graduates career start.
\end{abstract}

Keywords: graduate, partial phases, professional reality contact, professional start, social pedagogy

\section{Profesní start}

Profesní start je dle Nového (1989) období, které je součástí životní dráhy člověka a patří svým časovým určení do období tzv. životních startů, společně např. se startem manželským. Nový (1989) uvádí, že životní starty člověka se odehrávají od jeho 15-30 let. Řada autorů nahlíží profesní start jako součást profesní dráhy jedince. Hroník (2007) rozlišuje jednotlivé fáze profesní dráhy, a to fázi př́ípravy, rozvoje, vrcholu, fázi "plateau" a útlumu. Fáze př́pravy zahrnuje dle stejného autora období studia a získávání prvních zkušeností v praxi. Můžeme tedy tvrdit, že Hroník (2007) období profesního startu jako takového na rozdíl od Nového (1989) nevymezuje. Někteří autoři tedy nevnímají období profesního startu jako ucelené, ale uvažují o existenci dílčích fází profesní dráhy. Authur a DeFillippi (in Baruch,

\footnotetext{
${ }^{1}$ Kvalitativní výzkumné šetření a prezentace jeho dílčích výsledků bylo umožněno díky podpoře z projektu: Škola: výzkum vnitřních procesů a vnějších podmínek jejího fungování (2009-2011), Grantová agentura České republiky, GD406/09/H040.
} 
2003, s. 61) naopak neuvažují o profesní dráze a kariéře ve smyslu jejího lineárního vývoje a existence jednotlivých fází. Autoři pojednávají o tzv. kariéře bez hranic (Boundaryless career) (Arhur \& DeFillippi in Baruch, 2003). Kariéra bez hranic naopak dle stejných autorů obsahuje různorodé zkušenosti a volby různých směrů profesního rozvoje, často v prostředí tzv. neomezených organizací. Vendel (2008) obohacuje fáze profesní dráhy o období tzv. kariérního moratoria. V tomto období člověk oddaluje významné rozhodnutí týkající se vlastní profesní dráhy, není např. připraven na ukončení studia, začátek plného působení ve zvolené profesi nebo na změnu profese. Volí tedy raději nějaký čas na rozmyšlenou nebo na obnovení síly před zásadním "krokem do neznáma". V rámci kariérního moratoria se člověk může věnovat pracovním př́ležitostem, které nemusí (zdánlivě) souviset $\mathrm{s}$ jeho budoucím uplatněním v rámci konkrétní profese (Vendel, 2008). Rozhodla jsem se tedy, že se zaměřím na období profesního startu $v$ životě absolventek studijního oboru Sociální pedagogika a poradenství a zjistím, zda je možné vysledovat $\mathrm{v}$ tomto období dílčí fáze a pokud ano, o jaké fáze se jedná a jaká jsou jejich specifika. Předpokládala jsem, že profesní start absolventek tohoto oboru bude mít svá specifika, např. protože sociální pedagogika existuje jako obor vysokoškolského studia, ale sociálního pedagoga nenajdeme v katalogu profesí (Kraus, 2008). $\mathrm{V}$ rámci tohoto textu se stručně zabývám obdobím pregraduální př́pravy absolventek. $\mathrm{V}$ předkládaném textu se věnuji fázím profesního startu absolventek, které se objevují během období jejich pregraduální prrípravy.

\section{Metodologie výzkumného šetření}

Výzkumným problémem realizovaného kvalitativního šetření je role kontaktu s realitou praxe v jednotlivých fázích profesního startu u absolventek studijního oboru Sociální pedagogika a poradenství. Pod pojem kontakt $\mathrm{s}$ realitou praxe můžeme zahrnout jednak zkušenosti absolventek v práci s lidmi, tak setkání s konkrétní organizací nebo s jejími zaměstnanci, lidmi z praxe. Jedná se o zkušenosti, u kterých předpokládáme, že mají na respondentky svůj vliv.

Cílem celého kvalitativního šetření bylo zjistit odpověd' na otázky: Jaké fáze profesního startu se v období pregraduální přípravy u absolventek objevují? Jakou roli v jednotlivých fázích profesního startu v období pregraduální př́pravy hraje kontakt s realitou praxe? Odpovědi na stanovené otázky jsem hledala pomocí hloubkových, polostrukturovaných rozhovorů. Struktura rozhovorů byla sestavena na základě vymezení profesního startu od Nového (1989) tak, aby bylo možné získat data o celém období profesního startu. První rozhovory bychom mohli nazvat jako přehledové. Následně jsem se $\mathrm{s}$ některými respondentkami znovu sešla a nahrála rozhovory doplňující. Získaná data jsem analyzovala pomocí techniky otevřeného kódování tak, že jsem si metodou "papír a tužka" rozdělila text na jeho dílčí části, většinou na věty nebo odstavce, a tyto části textu jsem pojmenovala (Švaříček \& Šed'ová et al., 2007). Následně došlo ke kategorizaci kódů (Švaříček \& Šed'ová et al., 2007) a ustanovení a charakteristice dílčích fází profesního startu.

Výzkumný vzorek byl vybrán podle několika kritérií. Dotazovala jsem se pěti žen, které aktuálně působí v "oboru", tzn., že se věnují některé z možných oblastí uplatnění absolventů studijního oboru Sociální pedagogika a poradenství. Jednou z možností uplatnění je doktorské studium a dráha výzkumníka. Nebylo však mým záměrem se zaměřit na respondentky, které aktuálně studují v doktorském studiu a působí v některém z výzkumných projektů. Dvěma oblastmi, ve kterých respondentky aktuálně působily, byla oblast pedagogické práce a oblast sociální práce. Dalším kritériem bylo ukončené navazující magisterské studium oboru Sociální pedagogika a poradenství. Respondentky jsou ve věku 26-29 let, mají bohaté 
profesní zkušenosti již z období před ukončením studia, jsou bezdětné. Délka praxe na aktuální pracovní pozici se různí. Pohybuje se od 3 měsíců do pěti let.

\section{Výsledky výzkumného šetření}

\subsection{Fáze ladění}

Fáze ladění probíhala u respondentek před samotným zahájením vysokoškolského studia. Ve fázi ladění bylo úkolem respondentek, na základě prožité zkušenosti s prací s lidmi, najít obor vysokoškolského studia, který by odpovídal oblasti jejich zájmu a zároveň by umožňoval další osobnostní a profesní rozvoj respondentek.

To je jako když si naladíš tu správnou stanici na rádiu. To jsem si ř́íkala jako, to je to ono. (...) A tam jsem pak fakt měla pocit, (...) že jsem opravdu už blízko toho, co opravdu chci dělat, že je to pro mě dostatečně zajímavý a dává mi to dostatečný prostor pro to se naplňovat a realizovat. (Monika)

Kontakt s realitou praxe ve fázi ladění představoval sebezkušenost, na základě které byly respondentky motivovány $\mathrm{k}$ získávání dalších poznatků $\mathrm{v}$ oblasti výchovného působení na jedince různých věkových skupin ve volném čase. Skrze téma volného času se respondentky setkaly se studijním oborem Sociální pedagogika a volný čas a dozvěděly se tak rovněž o existenci oboru Sociální pedagogika a poradenství. Kontakt s realitou praxe představoval motiv k dalšímu studiu a zároveň možnost, jak spojit "př́ijemné s užitečným".

\subsection{Rozčarování a fáze uplatňování metody "pokus a omyl"}

V této fázi se respondentky sžívaly se svou rolí vysokoškolského studenta, přičemž roli studenta můžeme v této fázi považovat za dominantní. Dochází zde $\mathrm{k}$ určitému rozčarování v momentě, kdy respondentky zjišt'ují, že studium oboru Sociální pedagogika a poradenství neústí do konkrétní profese. Zároveň však oceňují prostor, který jim studium dává.

Já jsem si asi neuměla vůbec představit, co z toho bude člověk konkrétně dělat. Tak ale všude jako bylo, že sociální pracovníci sem tam, jo. Tak jsem si říkala, při nejhorším skončím na ňákým úruadě. A až při tom studiu mi vlastně začalo docházet, jak je to vlastně široký a kolik těch možností tam je, že se do toho dá napasovat spousta věcí. (Kristýna)

Ve fázi uplatňování metody pokus a omyl si respondentky zajišt'ovaly kontakt s realitou praxe dvěma způsoby. První cesta zajišt'ování kontaktu s realitou praxe byla rámována předmětem povinných, krátkodobých praxí. Krátkodobé praxe iniciované vysokou školou byly nahlíženy jako nástroj podpory pro studenty, kteří byli nerozhodní ve výběru preferované cílové skupiny. Druhou cestu představuje vlastní aktivita respondentek v rámci dobrovolnických činností, zájmových aktivit souvisejících s oborem studia, nebo placených brigád v "oboru". Kontakt $\mathrm{s}$ realitou praxe zde představuje prŕležitost pro nácvik profesních zkušeností "nanečisto". Respondentky uplatňují metodu "pokus a omyl", často zde nefiguruje žádná organizace nebo jiná autorita, která by nabývání profesních zkušeností korigovala. Na základě vlastní zkušenosti si respondentky dělají představu o tom, co v práci s konkrétní cílovou skupinou funguje a co nefunguje.

Takže možná pokus omyl to pro mě bylo. Jo, ježišmarjá, kolikrát jsem já šla z tý školky vyřízená. Ty děcka mě prostě totálně úplně sežraly, protože aktivita, kterou jsem si pro ně nachystala, byla prostě absolutně nezajímavá. A prostě ty tříletý děcka mi řekly, že je to úplně blbý a že já su teda hrozná a že oni to teda dělat nebudou a že si chcou skákat na nějakým skákacím hradu. Tak to mě vždycky dostalo. Ale to je o tom, jakoby být tomu otevřená, nenechat se zlomit, zkoušet. A ono to pak prostě někdy přijde... (Monika)

$\mathrm{V}$ této fází dochází $\mathrm{k}$ hledání vhodné cílové skupiny prostřednictvím kontaktu $\mathrm{s}$ realitou praxe. Některé respondentky o své cílové skupině rozhodly již během fáze ladění a proto pro 
ně představuje ve fázi uplatňování metody "pokus a omyl" kontakt s realitou praxe utvrzení o preferované cílové skupině. Pro jiné respondentky kontakt s realitou praxe umožňuje experimentování s dalšími cílovými skupinami. U jiných respondentek lze indetifikovat spíše konzervativní př́stup $\mathrm{k}$ zajišs'ování kontaktu s realitou praxe, kdy se $\mathrm{v}$ této fázi rozhodnou pro určité aktivity a pokračují v nich, aniž by zjištovaly své další možné oblasti uplatnění a vyhovující cílové skupiny klientů.

\subsection{Profesní rozvoj versus kariérní moratorium}

Jak již bylo uvedeno výše, některé respondentky měly spíše konzervativní přístup $\mathrm{k}$ zajišt'ování své vlastní praxe a k experimentování s cílovými skupinami, a po celou dobu studia se věnovaly stejným aktivitám. Fáze profesního rozvoje v konkrétní organizaci se od předchozí fáze odlišuje především tím, že respondentky získaly formální kvalifikaci. Záleželo však na přístupu respondentek k vlastnímu profesnímu rozvoji. Některé respondentky v této fázi měly potřebu intenzivního profesního rozvoje $\mathrm{v}$ práci $\mathrm{v}$ lidmi a využily získané kvalifikace pro hledání práce "v oboru". Pro tyto respondentky se stává konkrétní organizace, její pracovníci a samotné proměnlivé prostředí organizací neziskového sektoru, dominantním aktérem profesního rozvoje. U dalších respondentek dochází ke změně preferované cílové skupiny, v souvislosti se změnami v mimoškolních aktivitách. Mimoškolní události ovlivňují koncipování studia respondentkami. „Takže jsem moc teda nevyhledávala takový ty předměty pro malý děti nebo o mateřských školkách nebo tak. Asi i tím, že jsem dělala $v$ tom teambuildingu nebo $\mathrm{v}$ těch firemních kurzech, tak mě to vzdělávání dospělých jakoby pak táhlo nejvíc." (Michaela)

S nabýváním profesních zkušeností dochází $\mathrm{k}$ vytváření tzv. předběžné typologie cílových skupin, kdy jsou respondentky schopné na základě vlastního kontaktu s realitou praxe pojmenovat preferované a nepreferované cílové skupiny. V této fázi dochází k upozad'ování role studenta, at' už si respondentky volí cestu intenzivního profesního rozvoje v konkrétní organizaci nebo cestu kariérního moratoria. Proměňuje se př́istup respondentek ke studiu, a to s ohledem na volbu předmětů, plnění studijních povinností a hodnocení informací ze školní výuky. Zvyšující se intenzita kontaktu s realitou způsobuje vyšší kritičnost respondentek v hodnocení školy a studia.

Na tom magistrovi už jsem byla mnohem víc kritická. $\mathrm{K}$ předmětům, k učitelům, k informacím. Už jsem si jakoby mnohem víc vybírala věci, které jsou pro mě zajímavější a pro mě budou důležitý a mezi těma, který jsem jakoby jen tak pasivně přijímala. A už jsem si to jakoby filtrovala, už jsem byla ovlivněná tou praxí. (Monika)

Pro jiné respondentky představovalo navazující magisterské studium spíše období kariérního moratoria. Některé respondentky prodlužují studium a získávají pracovních zkušeností i "mimo obor".

Ale na toho magistra jsem cítila, že jdu hodně jenom proto, že chci být ještě student a že to bakalářský vzdělání bude mít za chvilku už každej a že to prostě pro mě nebyl ňákej ten titul, kterej si myslím, že bych měla mít. A to jsem jakoby chtěla víc. Ale no, pak jsem ho jakoby dělala čtyřri roky..." (Michaela)

U některých respondentek přichází krize smyslu studia, která způsobuje určité váhání nad dosavadním profesním vývojem a zvažování dalších možností. Pro některé respondentky se postupně stává vzdělání a nabyté zkušenosti prostředkem obživy na cestě postupné změny profese. "...tak já už vlastně v momentě, kdy jsem to ukončila, tak jsem věděla, že jakoby to dělat nechci. A že vlastně jakoby to chci jenom jako ukončit, aby se uzavřela jedna kapitola a tak to dopadlo. Že vlastně jsem dostudovala obor, který jsem nechtěla dělat." (Simona) Šok z reality přichází na začátku intenzivního působení v praxi. Některé respondentky zažívaly šok $\mathrm{z}$ reality již během studia, jiné až po jeho ukončení. Šok z reality je u absolventek studijního 
oboru o to intenzivnější, že vystudovaný obor neústí do profese sociálního pedagoga a úkolem absolventek je profesní adaptace (Farková, 2009) na roli sociálního pracovníka. "Takže to bylo tak, že jsem se těšila, ale pak když jsem postupně jako zjišt'ovala, o čem všem to je, dělat prostě někde sociálního pracovníka a dělat někde tu sociální práci, tak to bylo prostě docela náročný..." (Renata)

\section{Závěr}

Prvním obdobím profesního startu u absolventek studijního oboru sociální pedagogiky a poradenství je období pregraduální přípravy, které se skládá z dílčích fází. Jednotlivé fáze je možné rozlišit dle povahy kontaktu s realitou praxe a jeho vlivu na průchod respondentek těmito fázemi. V období pregraduální př́pravy jsem u respondentek identifikovala fázi ladění, kdy kontakt $\mathrm{s}$ realitou praxe představuje důležitý moment $\mathrm{v}$ procesu hledání vhodného oboru vysokoškolského studia. Kontakt $\mathrm{s}$ realitou praxe představuje sebezkušenost a ověření vlastních kompetencí respondentek. Navíc zvyšuje motivaci k zjišt’ování dalších informací o tématu výchovy dětí ve volném čase. Respondentky rovněž hledají takové zaměření studia, které by umožnilo jejich osobnostní rozvoj.

Rozčarování a období uplatňování metody "pokus a omyl" zahrnuje přibližně období bakalářského studia. Kontakt s realitou praxe zde představuje utvrzení o preferované cílové skupině prostřednictvím školních praxí, dobrovolnických a zájmových aktivit nebo placených brigád "v oboru". Během procesu získávání zkušeností v práci s lidmi zde nefiguruje konkrétní organizace, která by tuto zkušenost korigovala. Dochází $\mathrm{k}$ intuitivnímu a nahodilému zkoušení různých způsobů práce s konkrétní cílovou skupinou nebo cílovými skupinami.

Ve třetí fázi se pro respondentky rýsují dvě různé cesty. Po získání kvalifikace může dojít $\mathrm{k}$ tzv. fázi intenzivního profesního rozvoje v konkrétní organizaci, kdy její prostředí, lidé z praxe a sama povaha neziskového sektoru působí jako dominantní aktér působení na profesní rozvoj respondentek. Dochází zde k vytváření tzv. předběžné typologie cílových skupin. Prohlubování zkušeností $\mathrm{z}$ praxe vede $\mathrm{k}$ pojmenování preferovaných a nepreferovaných cílových skupin, př́padně $\mathrm{k}$ radikální změně cílové skupiny oproti předchozímu období studia. Druhou cestou je fáze kariérního moratoria, kdy respondentky prodlužují studium, zažívají krizi smyslu v souvislosti s nabýváním jiných, než profesních zkušeností z praxe "v oboru". Šok z reality jde ruku v ruce s intenzivnějším působením respondentek v praxi, bez ohledu na to, kdy dojde $\mathrm{k}$ ukončení studia. Tento zážitek navíc umocňuje požadavek na zvládnutí konkrétní profesní role.

Lze předpokládat, že jednotlivé fáze profesního startu se u absolventek budou odlišovat a objevovat se $\mathrm{v}$ různém pořadí. Zároveň můžeme považovat návrh fází profesního startu absolventek studijního oboru Sociální pedagogika a poradenství za předběžný, nebot' se jedná o dílčí výsledky kvalitativního výzkumného šetření.

\section{Literatura}

Baruch, Y. (2004) Transforming careers: from linear to multidirectional career paths. Organisational and individual perspective. Career Development International, 9(1), 58-73. Dostupné z http://www.wallnetwork.ca/inequity/transforming_careers.pdf

Farková, M. (2009). Dospělost a její variabilita. Praha: Grada publishing.

Hroník, F. (2007). Rozvoj a vzdělávání pracovnikủ. Praha: Grada publishing.

Kraus, B. (2008). Základy sociální pedagogiky. Praha: Portál. 
Nový, L. (1989). Životni dráha jako sociologický problém. Brno: Univerzita J. E. Purkyně.

Švaříček, R., \& Šed'ová, K. (Eds.). (2007). Kvalitativni výzkum v pedagogických vědách. Praha: Portál. Vendel, Š. (2008). Kariérni poradenství. Praha: Grada publishing.

\section{Kontakt}

Mgr. Martina Kánská

Masarykova univerzita

Filozofická fakulta, Ústav pedagogických věd

Arna Nováka 1, 60200 Brno

e-mail: 109639@phil.muni.cz

\section{Bibliografické údaje}

Kánská, M. (2011). Profesní start absolventek studijního oboru Sociální pedagogika a poradenství období pregraduální př́ípravy. In T. Janík, P. Knecht, \& S. Šebestová (Eds.), Smíšený design v pedagogickém výzkumu: Sborník př́spěvků z 19. výroční konference České asociace pedagogického výzkumu (s. 280-285). Brno: Masarykova univerzita.

Dostupné z: http://www.ped.muni.cz/capv2011/sbornikprispevku/kanska.pdf

doi: 10.5817/PdF.P210-CAPV-2012-22 